\title{
Penerapan Model Pembelajaran Direct Instruction dengan Media Gambar untuk Meningkatkan Prestasi Belajar IPS
}

\author{
Ni Made Sri Murjani*
}

SMP Negeri 2 Gianyar

\begin{abstract}
Abstrak
Penelitian ini dilaksanakan di SMP Negeri 2 Gianyar pada siswa kelas IX H yang kemampuannya untuk materi pelajaran IPS masih tergolong sangat rendah. Tujuan penulisan penelitian tindakan kelas ini adalah untuk meningkatkan prestasi belajar IPS siswa kelas IX H SMP Negeri 2 Gianyar pada semester I tahun pelajaran 2018/2019 melalui penerapan model pembelajaran Direct Instruction dengan media gambar. Metode pengumpulan datanya adalah tes prestasi belajar. Metode analisis datanya adalah deskriptif kuantitatif. Hasil yang diperoleh dari penelitian ini adalah penerapan model pembelajaran Direct Instruction dengan media gambar dapat meningkatkan prestasi belajar IPS siswa kelas IX H. Ini terbukti dari hasil yang diperoleh pada awalnya dengan nilai rata-rata 67,50, pada siklus I menjadi 75,00 dan pada siklus II meningkat menjadi 80,88 Ketuntasan belajar meningkat dari 32,35\% pada awal pembelajaran menjadi $73,52 \%$ pada siklus I dan $94,11 \%$ pada siklus II. Kesimpulan yang diperoleh dari penelitian ini adalah penerapan pembelajaran Direct Instruction dengan media gambar dapat meningkatkan prestasi belajar IPS siswa kelas IX H semester I SMP Negeri 2 Gianyar tahun pelajaran 2018/2019.
\end{abstract}

\author{
Keywords: \\ Model Pembelajaran \\ Direct Instruction, \\ Media Gambar, \\ Prestasi Belajar
}

\section{PENDAHULUAN}

Depdiknas (2003:5) menjabarkan aturan yang jelas untuk mencapai tujuan pembelajaran yang diharapkan, yaitu dengan mengembangkan proses belajar yang menyenangkan, memperhatikan keinginan siswa, membangun pengetahuan dari apa yang diketahui siswa, menciptakan suasana kelas yang mendukung kegiatan belajar, memberikan kegiatan yang sesuai dengan tujuan pembelajaran, memberikan kegiatan yang menantang, memberikan kegiatan yang memberi harapan keberhasilan, menghargai setiap pencapaian siswa.

Lampiran Permendiknas RI No. $22(2006,416)$ juga menyebutkan bahwa, untuk meningkatkan keefektifan pembelajaran, sekolah diharapkan menggunakan teknologi informasi dan komunikasi seperti komputer, alat peraga, atau media lainnya. Sementara itu, dalam Permendiknas RI No. 41 (2007: 6) disebutkan bahwa proses pembelajaran pada setiap satuan pendidikan dasar dan menengah harus interaktif, inspiratif, menyenangkan, menantang, dan memotivasi siswa untuk berpartisipasi aktif serta memberikan ruang yang cukup bagi prakarsa, kreativitas dan kemandirian sesuai dengan bakat, minat, dan perkembangan fisik serta psikologis siswa.

Karena itulah, sebagai agen pembelajaran guru sebagai ujung tombak pendidikan dan keberhasilan pelaksanaan UU Sistem Pendidikan, diharapkan memiliki pengetahuan dan keterampilan yang berhubungan dengan tugas dan tanggung jawabnya selaku guru yang profesional. Guru yang profesional harus memiliki seperangkat kompetensi (pengetahuan, keterampilan dan perilaku) untuk mampu menjalankan tugas yang diembannya. Berdasarkan UU no. 14 Tahun 2005 tentang Guru dan Dosen pada Bab IV Pasal 10 ayat (1) menyatakan bahwa Kompetensi guru sebagaimana dimaksud dalam Pasal 8

\footnotetext{
* Corresponding author. 
meliputi kompetensi pedagogik, kompetensi kepribadian, kompetensi sosial, dan kompetensi profesional yang diperoleh melalui pendidikan profesi.

Hal yang tidak kalah pentingnya adalah pemahaman guru tentang proses pembelajaran dapat berlangsung aktif, kreatif dan amenarik. Hal ini akan bisa terjadi bila dalam diri siswa tumbuh rasa ingin tahu, mencari jawaban atas pertanyaan, memperluas dan memperdalam pemahaman dengan menggunakan metode yang efektif. Rasa ingin tahu siswa muncul dan terlihat ketika sudah mulai mengajukan pertanyaan-pertanyaan. Pertanyaan inilah nantinya yang akan menjadi bahan pembelajaran untuk dicari jawabannya bersama-sama antara guru dan siswa. Agar mampu menjawab semua pertanyaan yang dilontarkan siswa dan memberikan dampak yang baik terhadap kelangsungan pembelajaran mereka, seorang guru harus benar-benar memiliki pengetahuan yang mendalam tentang materi yang diajarkan sehingga dia layak disebut seorang guru yang kompeten.

Pembelajaran yang dilakukan antara guru dan siswa hendaknya mengacu pada peningkatan aktivitas dan partisipasi siswa. Guru tidak hanya melakukan kegiatan penyampaian pengetahuan, keterampilan, dan sikap kepada siswa, akan tetapi guru diharapkan mampu membawa siswa untuk aktif dalam berbagai bentuk belajar, berupa belajar penemuan, belajar mandiri, belajar kelompok, belajar memecahkan masalah, dan sebagainya. Hasil belajar siswa selain dipengaruhi oleh metode pembelajaran juga dipengaruhi oleh partisipasi siswa. Jika siswa aktif dan berpartisipasi dalam pembelajaran, maka tidak hanya aspek prestasi saja yang diraihnya namun ada aspek lain yang diperoleh yaitu aspek afektif dan aspek sosial. Menurut Kusminah (2012) Model pembelajaran adalah kerangka konseptual yang melukiskan prosedur yanng sistematis dalam mengorganisasikan pengalaman belajar untuk mencapai tujuan belajar tertentu, dan berfungsi sebagai pedoman bagi para perancang pembelajaran dan para pengajar dalam merencpeserta didikan dan melakspeserta didikan aktivitas pembelajaran benar-benar merupakan kegiatan bertujuan yang tertata secara sistematis. Menurut Surahman (2017) Ilmu Pengetahuan Sosial adalah mata pelajaran di sekolah yang di desain atas dasar fenomena, masalah dan realitas sosial dengan pendekatan interdisipliner yang melibatkan berbagai cabang ilmu-ilmu sosial dan humaniora seperti kewarganegaraan, sejarah, geografi, ekonomi, sosiologi, antropologi, pendidikan. Karena itu, IPS dapat dikatakan sebagai studi mengenai perpaduan antara ilmu-ilmu dalam rumpun ilmuilmu sosial dan juga humaniora untuk melahirkan pelakupelaku sosial yang dapat berpartisipasi dalam memecahkan masalah-masalah sosio kebangsaan.

Untuk dapat membelajarkan siswa sesuai apa yang diharapkan, guru harus didukung dengan pengetahuan dan pemahaman standar yang mesti dikuasai sesuai metodik dan didaktik, agar dapat mengelola secara profesional mata pelajaran yang diampunya. Kompetensi pedagogik yang dimaksud menurut Mulyasa, (2011: 75) sekurang-kurangnya meliputi: a) pemahaman wawasan atau landasan kependidikan; b) pemahaman terhadap peserta didik; c) pengembangan kurikulum/silabus; d) perancangan pembelajaran; e) pelaksanaan pembelajaran yang mendidik dan dialogis; f) pemanfaatan teknologi pembelajaran; g) evaluasi hasil belajar; dan h) pengembangan peserta didik untuk mengaktualisasikan berbagai potens yang dimilikinya.

Wardani dan Julaeha (dalam Modul IDIK, 4307: 1-30) mempersyaratkan 7 keterampilan yang mesti dikuasai guru dalam melaksanakan pembelajaran, untuk dapat disebut professional yaitu: 1) keterampilan bertanya, 2) keterampilan memberi penguatan, 3) keterampilan mengadakan variasi, 4) keterampilan menjelaskan, 5) keterampilan membuka dan menutup pelajaran, 6) keterampilan membimbing diskusi, 7) keterampilan mengelola kelas. Keterampilan-keterampilan ini berhubung dengan kemampuan guru untuk menguasai dasar-dasar pengetahuan yang berhubungan dengan persiapan dan pelaksanaan proses pembelajaran yang akan memberikan dukungan terhadap cara berpikir siswa yang kreatif dan imajinatif.

Sebagaimana dipahami proses pembelajaran secara umum merupakan kegiatan transformasi pengetahuan dan kemampuan guru kepada peserta didiknya.Terkadang ada guru yang secara individu disebut pintar tetapi tidak memiliki kemampuan yang memadai untuk menyampaikan pengetahuan dan pemahaman yang dimilikinya, maka tentu proses pembelajaran tidak akan berhasil dengan baik. Kadang ada guru yang memiliki prestasi biasa-biasa saja tetapi dalam menyampaikan dan mengelola pembelajaran lebih kreatif dan inovatif serta memahami cara penyampaiannya bisa jadi menyebabkan proses pembelajaran akan berhasil dengan baik. Di antara keduanya tentu yang paling sesuai adalah memiliki kemampuan profesionalisme keguruan dan mampu menyampaikan dengan efektifdan efisien demi terciptanya proses dan tujuan pembelajaran yang diharapkan.

Harapan nyata yang diinginkan di lapangan terkadang tidak selalu sejalan. Banyak faktor yang menjadi penyebab tidak terwujudnya harapan tersebut, seperti: kurangnya kemauan guru mengembangkan model pembelajaran, kemampuan guru memahami inti pembelajaran, kemampuan guru melaksanakan teori-teori pembelajaran terbaru, kemampuan guru memahami karakteristik peserta didik, 
kelengkapan sarana prasarana yang ada di sekolah, kemampuan anak mengikuti proses pembelajaran, dan lain-lain.

Sehubungan dengan proses pembelajaran yang berlangsung di SMP Negeri 2 Gianyar dari hasil pengumpulan data awal didapat nilai rata-rata siswa kelas IX H pada mata pelajaran IPS baru mencapai 67,50 dengan ketuntasan belajar hanya mencapai 32,35\%. Hasil tersebut tentu tidak sesuai dengan harapan keberhasilan pendidikan yang ditetapkan yaitu 75,00. Tentang pelajaran yang disampaikan, jika pelajaran sempat diterima peserta didik dan belum berhasil, boleh jadi penyebabnya dikarenakan keterbatasan kemauan guru dalam menerapkan semua keilmuan yang dikuasai demi pencapaian hasil maksimal dalam pembelajaran.

Selanjutnya peneliti/guru melaksanakan perbaikan pembelajaran dengan menerapkan model pembelajaran Direct Instruction (pengajaran langsung) dengan media gambar supaya dapat meningkatkan prestasi belajar IPS siswa khususnya siswa kelas IX H di SMP Negeri 2 Gianyar.

Susiana (2014), hasil penelitian menunjukkan bahwa: (1) motivai belajar kelas eksperimen masuk kriteria sangat tinggi 71\%; (2) motivai belajar kelas kontrol masuk kriteria sangat tinggi 28\% ; (3) pencapaian kompetensi kelas eksperimen kategori tuntas 84\%; (4) pencapaian kompetensi kelas kontrol kategori tuntas sebanyak 33\%; (5) pendapat peserta didik tentang penerapan model DI menunjukkan bahwa 27 siswa (87\%) pada kategori sangat senang; (6) terdapat pengaruh penerapan model DI terhadap motivasi belajar antara kelas eksperimen dan kelas kontrol, dibuktikan dengan hasil perhitungan uji $t(t-$ test) dengan $\mathrm{t}$ hitung $0,000<\mathrm{t}$ table 0,05; (7) terdapat pengaruh penerapan model DI terhadap pencapaian kompetensi pembuatan desain busana antara kelas eksperimen dan kelas kontrol, yang dibuktikan dengan hasil perhitungan uji t ( $\mathrm{t}$-test) dengan $\mathrm{t}$ hitung 0,000< t table 0,05.

Elistina (2014) Dari hasil tindakan siklus I diperoleh ketuntasan belajar yang mendapatkan nilai lebih dari 65 sebanyak 25 siswa atau sebesar 83,3\% dari 30 siswa dengan nilai rata-rata 69,5, sedangkan 5 siswa memperoleh nilai kurang dari 65 atau sebesar 16,7\% dari 30 siswa. Hasil tindakan siklus II diperole h ketuntasan belajar yang mendapatkan nilai lebih dari 65 sebanyak 28 siswa atau sebesar 93,3\% dari 30 siswa dengan nilai rata-rata 75,7, sedangkan 2 siswa memperoleh nilai kurang dari 65 atau sebesar 6,7\% dari 30 siswa. Dengan demikian dapat disimpulkan bahwa penerapan model Pembelajaran Langsung (Direct Instruction) dapat meningkatkan hasil belajar siswa kelas V SDN 5 Basi.

Menrurut Mersita (2015) Penerapan model pembelajaran langsung (Direct Instruction) merupakan variasi model yang dapat diterapkan pada kompetensi dasar memilih sistem penyimpanan arsip yang sesuai yang dapat membantu guru dan siswa dalam mengatasi masalah dalam proses belajar mengajar. Dengan adanya peningkatan aktivitas dan hasil belajar yang diperoleh dengan penerapan model pembelajaran langsung (Direct Instruction) diharapkan dapat meningkatkan kualitas pembelajaran dan mutu pendidikan di sekolah. Menurut Marlina (2015) Model pengajaran langsung memberikan kesempatan siswa belajar dengan mengamati secara selektif, mengingat dan menirukan apa yang dimodelkan gurunya. Oleh karena itu hal penting yang harus diperhatikan dalam menerapkan model pengajaran langsung adalah menghindari menyampaikan pengetahuan yang terlalu kompleks.

Menurut Watanabe (2013) Model instruksi langsung adalah suatu model pengajaran yang terdiri dari penjelasan guru mengenai konsep atau keterampilan baru, melibatkan guru bekerja dengan siswa secara individual, atau dalam kelompok-kelompok kecil. Pembelajaran Direct Instruction (pengajaran langsung) dengan media gambar adalah strategi mengajar yang mengkombinasikan rasa ingin tahu siswa. Penggunaan strategi ini untuk meningkatkan pengembangan keterampilan berpikir kritis melalui kegiatan belajar. Penerapan strategi pembelajaran Direct Instruction (pengajaran langsung) dengan media gambar ini merupakan upaya untuk membangkitkan rasa ingin tahu siswa. Dorongan itu berkembang melalui proses merumuskan pertanyaan, merumuskan masalah, mengamati, dan menerapkan informasi baru dalam meningkatkan pemahaman mengenai sesuatu masalah. Rasa ingin tahu itu terus ditumbuhkan untuk meningkatkan semangat bereksplorasi sehingga siswa belajar secara aktif.

\section{METODE PENELITIAN}

Penelitian ini merupakan penelitin tindakan kelas yang akan dilaksanakan dalam dua siklus. Jika pada siklus pertama prestasi belajar IPS siswa belum memenuhi kriteria keberhasilan, maka berdasarkan hasil refleksi akan dilakukan perbaikan pada siklus seanjutnya. Secara operasional prosedur dasar pengembangan tindakan yang akan dilakukan dapat dijabarkan sebagai berikut:

Untuk penelitian ini penulis memilih rancangan penelitian tindakan yang disampaikan oleh Arikunto (2010:6) seperti terlihat pada gambar berikut. 


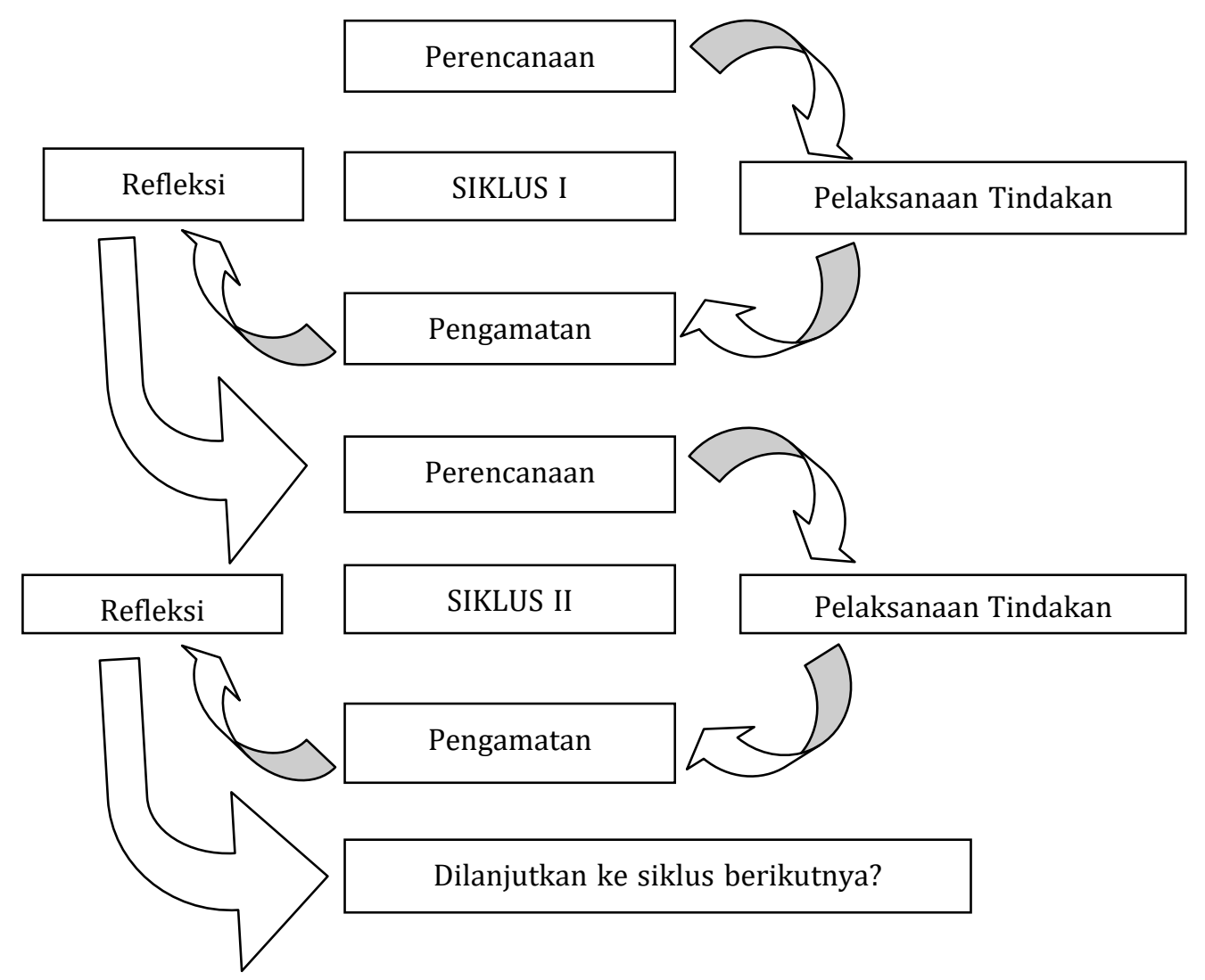

Gambar 1. Gambar Rancangan Penelitian Tindakan Kelas

Berdasarkan bagan, tahapan kegiatan penelitian dapat dijelaskan sebagai berikut:

\section{Perencanaan Tindakan}

Adapun perencanaan yang dilakukan untuk melaksanankan penelitian tindakan kelas adalah sebagai berikut: a) Berkoordinasi dengan kepala sekolah untuk melaksanakan penelitian, b) Melakukan refleksi awal dengan melihat prestasi belajar IPS siswa sebelum dilaksanakan penelitian, c) Melakukan analisis kurikulum untuk mengetahui standar kompetensi, kompetensi dasar dan menyusun silabus yang disampaikan kepada siswa dengan menggunakan sintak model pembelajaran Direct Instruction dengan media gambar, d) Menyusun Rencana Pelaksanaan Pembelajaran (RPP) dilengkapi LKS yang dirancang. Langkah-langkah pembelajarannya diarahkan pada sintak model pembelajaran Direct Instruction dengan media gambar untuk materi yang diajarkan, e) Menyusun lembar penilaian dan tes/evaluasi berupa tes prestasi belajar dan kuesioner motivasi belajar, f) Membuat ringkasan materi yang dibahas, g) Membuat instrumen untuk penelitian tindakan kelas berupa lembar refleksi

2. Pelaksanaan Tindakan

Dalam pelaksanaan ini disusun sesuai dengan tahap pelaksanaan penerapan model pembelajaran Direct Instruction dengan media gambar dalam mata pelajaran IPS untuk mengetahui prestasi belajar siswa. Pada setiap siklus penelitian terdiri dari 4 kali pertemuan. 3 kali pertemuan untuk melaksanakan proses pembelajaran dan 1 kali pertemuan untuk melaksanakan evaluasi atau tes prestasi belajar dan mengukur motivasi belajar siswa. Langkah-langkahnya adalah sebagai berikut.

Persiapan pada awal pembelajaran

Pada tahap ini, kegiatan yang dilaksanakan adalah mempersiapkan perangkat pembelajaran, membentuk kelompok learning komunity, menetukan skor awal, mengatur tempat duduk dan melakukan kegiatan apersepsi.

Pelaksanaan pembelajaran

Langkah-langkah dalam pelaksanaan tindakan ini adalah dilaksanakan sesuai dengan Rencana Pelaksanaan Pembelajaran (RPP) yang telah disusun dan disiapkan dengan menerapkan tahap-tahap model pembelajaran Direct Instruction dengan media gambar. 


\section{Observasi / Evaluasi}

Pada pertemuan ke 4, guru melaksanakan tes prestasi belajar dan mengukur motivasi belajar siswa. Kegiatan yang dilakukan pada tahap evaluasi yaitu memberikan lembar tes evaluasi kepada siswa yang bertujuan untuk mengetahui prestasi belajar siswa dan kuesioner motivasi belajar untuk mengetahui tingkat motivasi belajar siswa setelah dilaksanakannya pembelajaran dengan model pembelajaran Direct Instruction dengan media gambar. Hasil evaluasi akan menjadi acuan bagi peneliti dalam merancang pembelajaran pada siklus berikutnya (siklus II).

\section{Refleksi}

Refleksi ini dilakukan untuk melihat dan mengkaji hasil tindakan pada siklus I mengenai prestasi belajar IPS dan motivasi belajar siswa. Hasil kajian tindakan siklus I ini, selanjutnya dipikirkan untuk dicari dan ditetapkan beberapa alternatif tindakan baru yang diduga lebih efektif untuk meningkatkan prestasi belajar IPS. Alternatif tindakan ini ditetapkan menjadi tindakan baru pada rencana tidakan dalam penelitian.

\section{ANALISIS DAN PEMBAHASAN}

Model Pembelajaran Direct Instruction (model pengajaran langsung) ini dirancang khusus untuk menunjang proses belajar siswa yang berkaitan dengan pengetahuan prosedural dan pengetahuan deklaratif yang terstruktur dengan baik, yang dapat diajarkan dengan pola kegiatan yang bertahap, selangkah demi selangkah. Hal ini sesuai dengan pendapat Arends (2001), yang menyatakan bahwa "The Direct Instruction model was specifically designed to promote student learning of procedural knowledge and declarative knowledge that is well structured and can be taught in a stepby-step fashion." Sedangkan Carin (1993) berpendapat bahwa Direct Instruction secara sistematis menuntun dan membantu siswa untuk melihat hasil belajar dari masing-masing tahap demi tahap. sementara Kardi (2001) mendefinisikan "Model Pembelajaran Langsung (MPL) adalah suatu strategi pembelajaran yang digunakan untuk mengajarkan konsep dan keterampilan." Apabila guru menggunakan model pembelajaran langsung ini, guru mempunyai tanggung jawab untuk mengidentifikasikan tujuan pembelajaran dan tanggungjawab yang besar terhadap penstrukturan isi/materi atau keterampilan, menjelaskannya kepada siswa, pemodelan/mendemonstrasikan yang dikombinasikan dengan latihan, memberikan kesempatan kepada siswa untuk berlatih menerapkan konsep atau keterampilan yang telah dipelajari serta memberikan umpan balik.

Salah satu media yang dapat dipadukan dengan model pembelajaran direct instruction adalah media gambar. Bentuk umum dari media gambar terangkum dalam pengertian dari media grafis. Karena media gambar merupakan bagian dari pembuatan media grafis.Sebelum kita nengetahui lebih lanjut mengenai media gambar ada baiknya kita mengetahui lebih dahulu pengertian dari media grafis.

Menurut (Tegeh, 2008) media grafis atau graphic material adalah suatu media visual yang menggunakan titik-titik, garis-garis, gambar-gambar, tulisan, atau symbol visual yang lain dengan maksud untuk menikthisarkan, menggambarkan, dan merangkum suatu ide, data kejadian. Batasan tersebut memberi gambaran bahwa media grafis merupakan media dua dimensi yang dapat dinikmati dengan menggunakan indra pengelihatan.

Kelebihan Media Gambar adalah sebagai berikut: a) Sifatnya konkrit. Gambar/ foto lebih realistis menunjukkan pokok masalah dibanding dengan media verbal semata, b) Gambar dapat mengatasai masalah batasan ruang dan waktu. Tidak semua benda, objek atau peristiwa dapat dibawa ke kelas, dan tidak selalu bisa, anak-anak dibawa ke objek tersebut, c) Media gambar dapat mengatasi keterbatasan pengamatan kita. Sel atau penampang daun yang tak mungkin kita lihat dengan mata telanjang dapat disajikan dengan jelas dalam bentuk gambar, d) Dapat memperjelas suatu masalah, dalam bidang apa saja dan untuk tingkat usia beberapa saja, sehingga dapat mencegah atau membetulkan kesalahpahaman, e) Murah harganya, mudah didapat, mudah digunakan, tanpa memerlukan peralatan yang khusus.

Berdasarkan penelitian yang telah dilakukan dengan menerapkan model pembelajaran Direct Instruction berbantuan media gambar didapatkan hasil sebagai berikut.

Data awal yang diperoleh dengan rata-rata 67,50 dengan ketuntasan belajar hanya mencapai $32,35 \%$ menunjukkan bahwa kemampuan siswa dalam mata pelajaran IPS masih sangat rendah mengingat kriteria ketuntasan belajar siswa untuk mata pelajaran ini di SMP Negeri 2 Gianyar adalah 75,00. Dengan nilai yang sangat rendah seperti itu maka peneliti mengupayakan untuk dapat meningkatkan prestasi belajar anak/siswa menggunakan metode/model pembelajaran Direct Instruction dengan media gambar. Akhirnya dengan penerapan metode/model pembelajaran Direct Instruction dengan media gambar yang benar sesuai teori yang ada, peningkatan rata-rata prestasi belajar anak/siswa pada siklus I dapat diupayakan dan mencapai rata-rata 75,00. Namun rata-rata tersebut 
belum maksimal karena hanya 19 siswa memperoleh nilai di atas KKM sedangkan 25 yang lainnya belum mencapai KKM. Sedangkan prosentase ketuntasan belajar mereka baru mencapai 73,52\%. Hal tersebut terjadi akibat penggunaan metode/model pembelajaran Direct Instruction dengan media gambar belum maksimal dapat dilakukan disebabkan penerapan model/metode tersebut baru dicobakan sehingga guru masih belum mampu melaksanakannya sesua alur teori yang benar.

Pada siklus ke II perbaikan prestasi belajar siswa diupayakan lebih maksimal dengan peneliti membuat perencanaan yang lebih baik, menggunakan alur dan teori dari metode/model pembelajaran Direct Instruction dengan media gambar dengan benar dan lebih maksimal. Peneliti giat memotivasi siswa agar giat belajar, memberi arahan-arahan, menuntun mereka untuk mampu menguasai materi pelajaran pada mata pelajaran IPS lebih optimal. Akhirnya dengan semua upaya tersebut peneliti mampu meningkatkan prestasi belajar siswa pada siklus II menjadi rata-rata 80,88 dengan presentase ketuntasan mencapai $94,11 \%$, hal ini menunjukkan terjadinya peningkatan yang sangat signifikan. Upaya-upaya yang maksimal tersebut menuntun pada suatu keberhasilan bahwa penerapan model/metode pembelajaran Direct Instruction dengan media gambar mampu meningkatkan prestasi belajar IPS siswa kelas IX H SMP Negeri 2 Gianyar pada semester I tahun pelajaran 2018/2019.

Hasil penelitian di atas, dapat dirangkum dan digambarkan pada pada tabel 01 dan gambar 02 berikut.

Tabel 1. Tabel Data Prestasi Belajar Siswa Kelas IX H SMP Negeri 2 Gianyar

\begin{tabular}{lllll}
\hline Data & Awal & Siklus I & Siklus II & Variabel \\
\hline Skor Nilai & 2295 & 2550 & 2750 & Prestasi Belajar IPS \\
Rata Rata Kelas & 67,50 & 75,00 & 80,88 & Dengan \\
Persentase Ketuntasan & $32,35 \%$ & $73,52 \%$ & $94,11 \%$ & KKM = 75 \\
\hline
\end{tabular}

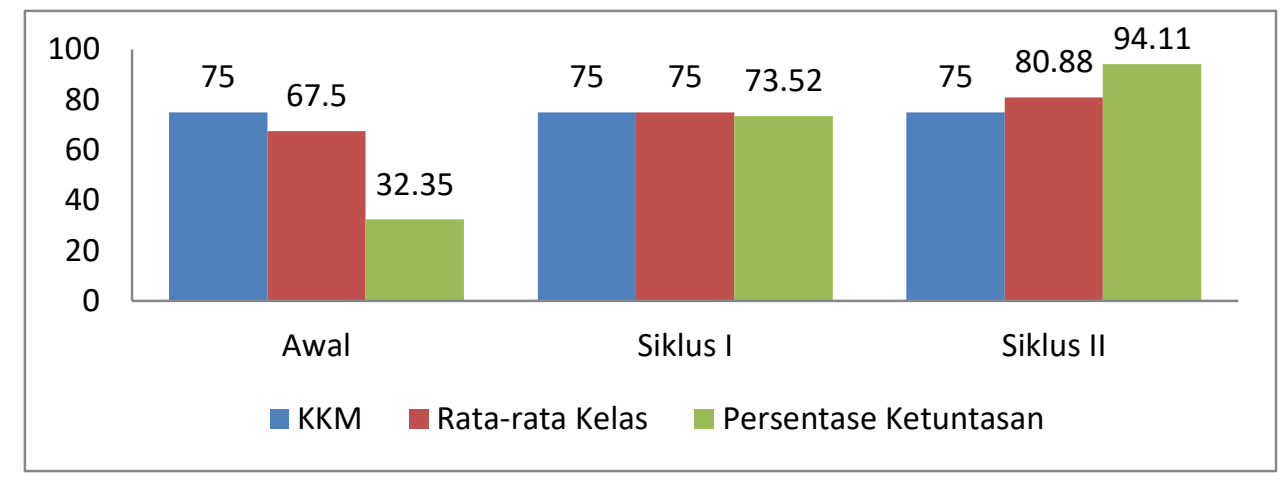

Gambar 2. Grafik Histogram Prestasi Belajar IPS Siswa Kelas IX H Semester I Tahun Pelajaran 2018/2019 SMP Negeri 2 Gianyar

Hasil penelitian ini sejalan dengan hasil penelitian yang dilakukan oleh Haryono (2016) yang berjudul Peningkatan Prestasi Belajar Mata Pelajaran Matematika Melalui Model Pembelajaran Direct Instruction Bagi Siswa Kelas IV Semester I Tahun Pelajaran 2015/2016 di SDN 3 Gemaharjo Kecamatan Watulimo Kabupaten Trenggalek. hasil penelitiannya menunjukkan bahwa: terjadi peningkatan dari pra siklus kje siklus I dan dari siklus I ke siklus II. Sesuai dengan hasil analisis, maka dapat disimpulkan bahwa: "Terjadi peningkatan prestasi belajar mata pelajaran Matematika setelah mjenerapkan model pembelajaran direct instruction bagi siswa kelas IV semester I tahun pelajaran 2015/2016 di SDN 3 Gemaharjo Kecamatan Watulimo Kabupaten Trenggalek.

\section{KESIMPULAN}

Dari pelaksanaan penelitian yang sudah dijabarkan pada bagian sebelumnya diperoleh kesimpulan bahwa tindakan yag peneliti laksanakan telah mampu meningkatkan prestasi belajar anak sesuai yang diinginkan. Bukti yang dapat disampaikan adalah: Dari data awal ada 23 siswa mendapat nilai dibawah KKM dan pada siklus I menurun menjadi 9 siswa dan siklus II hanya 2 siswa mendapat nilai di bawah KKM, Nilai rata-rata awal 67,50 naik menjadi 75,00 pada siklus I dan pada siklus II naik menjadi 80,88 , Dari data awal siswa yang tuntas hanya 11 orang sedangkan pada siklus I menjadi lebih banyak yaitu 25 siswa dan pada siklus II sebanyak 32 siswa sudah memenuhi KKM. 
Semua bukti tersebut dapat dicapai adalah akibat kesiapan dan kerja keras peneliti dari sejak pembuatan proposal, review, penyusunan kisi-kisi dan instrumen penelitian, penggunaan sarana trianggulasi data sampai pada pelaksanaan penelitian yang diakhiri dengan penulisan laporan ini. Data tersebut membuktikan bahwa penerapan model pembelajaran Direct Instruction dengan media gambar dapat meningkatkan prestasi belajar IPS siswa kelas IX H pada semester I tahun pelajaran 2018/2019.

\section{DAFTAR PUSTAKA}

Arends, R.I.. 2001. Exploring Teaching: An Introduction to Education. New. York: Mc Graw-Hill Companies.

Arikunto, S. 2010. Prosedur Penelitian Suatu Pendekatan Praktik. Jakarta: Rineka Cipta.

Carin dan sund. 1993. Metodologi Pembelajaran IPA. Jakarta: Bumi aksara.

Depdiknas .2003. Undang-undang RI No.20 tahun 2003.tentang sistem pendidikan nasional.

Haryono. 2016. Peningkatan Prestasi Belajar Mata Pelajaran Matematika Melalui Model Pembelajaran Direct Instruction Bagi Siswa Kelas IV Semester I Tahun Pelajaran 2015/2016 di SDN 3 Gemaharjo Kecamatan Watulimo Kabupaten Trenggalek. JUPEDASMEN, Volume 2, Nomor 3, Desember 2016.

Kardi, Soeparman dan Mohamad Nur. 2000. Pengajaran Langsung. Surabaya : Universitas Negeri Surabaya Universiti Press.

Kusminah. 2012. Pengembangan Model Pembelajaran Induktif Kata Bergambar Bermuatan Nilai-Nilai Pendidikan Karakter Aspek Membaca Permulaan Sekolah Dasar. Journal of Educational Research and Evaluation Vol. 1 No. 2 Hal. 113-119. http://journal.unnes.ac.id/sju/index.php/jere.

Marlina, Hamid, Marwan. 2015. Pengaruh Penerapan Model Pengajaran Langsung (Direct Instruction) terhadap Hasil Belajar Siswa Kelas X Man Peudada pada Materi Kebutuhan Manusia. Jurnal Sains Ekonomi dan Edukasi Vol. III, No. 1 Hal. 1-10.

Mersita, Neni, Muhsin. 2015. Penerapan Model Pembelajaran Langsung (Direct Instruction) untuk Meningkatkan Aktivitas dan Hasil Belajar pada Mata Pelajaran Kearsipan Siswa Kelas XI AP SMK YPE Nusantara Slawi. Economic Education Analysis Journal Vol. 4 No. 3 Hal. 634-648. http://journal.unnes.ac.id/sju/index.php/eeaj.

Mulyasa. 2011. Manajemen Berbasis Sekolah, Konsep, strategi dan. Implementasi. Bandung : PT Remaja Rosdakarya.

Tegeh, I Made. 2008. Media Pembelajaran. Singaraja: Institut Keguruan dan Ilmu Pendidikan.

Elistina.2014. Penerapan Model Pembelajaran Langsung (Direct Instruction) Berbantuan Gambar Untuk Meningkatkan Hasil Belajar Siswa Pada Mata Pelajaran IPA di Kelas V SDN 5 Basi Kecamatan Basidondo Tolitoli. Jurnal Kreatif Tadulako Online Vol. 4 No. 9.

Surahman, Edy, Mukminan. 2017. Peran Guru IPS Sebagai Pendidik dan Pengajar dalam Meningkatkan Sikap Sosial dan Tanggung Jawab Sosial Siswa SMP. Harmoni Sosial: Jurnal Pendidikan IPS Vol. 4 No 1 Hal. 1-13.

Susiana Ratih. 2014. Pengaruh Model Direct Instruction Berbantuan Multimedia Terhadap Motivasi Belajar dan Pencapaian Kompetensi Pembuatan Desain Busana. Jurnal Pendidikan Vokasi.

Watanabe, M., McLaughlin, T. F., Weber, K. P., \& Shank, L. (2013). The Effects of Using Direct Instruction to Teach Coin Counting and Giving. International Journal of Basic and Applied Science Vol. 02 No. 01 , 150-159. 